\title{
Purification of Industrial Wastewater from Methylene Blue (MB) Dye Using Organic and Inorganic Sol-gel Glasses
}

\author{
Hayam F. Mohamed ${ }^{\mathrm{a} *}$, Boshra M. Awad ${ }^{\mathrm{a}}$, ShahinazAbd El RahmanI ${ }^{\mathrm{b}}$,Mayyada M.H. EI- \\ Sayed ${ }^{\text {b, }}$
}

${ }^{a}$ ChemistryDepartment,Faculty of Women for Arts, Science and Education, Ain Shams University, 1 AsmaaFahmy Street, Heliopolis 11757, Cairo, Egypt.

${ }^{\mathrm{b}}$ Chemistry Department, The American University in Cairo, AUC Avenue, P.O. Box 74, New Cairo 11835, Egypt.

\begin{abstract}
Organic and inorganic-doped sol-gel glasses have been synthesized via thermal followed by microwave treatment. Tetramethoxysilane (TMEOS) was used as a precursor, whereas dopants used were Neodymium oxide, Urea (carbamide) or Thiourea (thiocarbamide) and the obtained formulations werereferred as $\mathrm{Nd}, \mathrm{U}$, and THU, respectively along with the undoped or plain glass (P). Colors of the as-prepared sol-gel glasses ranged from transparent colorless $(\mathrm{P})$ to opaque dark purple $(\mathrm{Nd})$. The latter colorcould be owed to the presence of the inorganic transition element oxide $\left(\mathrm{Nd}_{2} \mathrm{O}_{3}\right)$.In addition, THU had the smallest particle size range $(<250$ microns), whereas the other three sol-gel glasses had larger particle sizes ranging from 250- 630 microns.Thesynthesized sol-gel glasses were tested for their capacity to adsorb and remove Methylene Blue (MB) dye from aqueous solutions. Uexhibited the highestsorptioncapacitiesof 12.6 and $2.6 \mathrm{mg} / \mathrm{g}$ with removal efficiencies of $50.3 \%$ and $83.2 \%$ at 12 and $2 \mathrm{mg} / \mathrm{L} \mathrm{MB}$, respectively. These values were almost twice and 1.7 times those obtained by $\mathrm{P}$ at the higher and lower MB concentrations, respectively which indicates that doping with urea enhanced sorption through introducing new functional groups.Fourier transform Infrared (FTIR)spectroscopy revealed that carbonyl group on urea could be responsible for adsorption via electrostatic interaction between the negatively charged carbonyl oxygen of urea and the positively charged nitrogen or sulfur on $\mathrm{MB}$, or through redox reactions between them.
\end{abstract}

Keywords: Sol-gel glasses,Microwave irradiation, Urea, Thiourea, Neodymium, Adsorption, Methylene Blue, Network, Industrial Wastewater purification.

*Correspondences: boshra.awad@ women.asu.edu.eg 


\section{Introduction}

In material science, the sol gel process is a method by which monomers are converted into a colloidal solution known as sol, which acts as the precursor for an integrated network of polymers or discrete particles. Typically, metal alkoxides (MOR) are commonly used as precursors.

In the past 50 years and with the tremendously growing world's population and the consequent heavy industrial activities, water stress levels increased dramatically as a result of depositing large quantities of pollutants such as heavy metals, dyes, emerging organic pollutants, and others, in surface and underground water. This results in a bad quality of drinking water and aquatic ecosystems, leading to serious health and environmental problems. Consequently, water purification or decontamination became of utmost importance. The conventional adsorbents used for water treatment still suffer from lack of efficiency, especially for some of the toxic and non-biodegradable organic pollutants. Hence, there is a great need to find alternative adsorbent materials that can improve the efficiency while being synthesized in a simple manner. The "sol-gel" technique is a promising technique for synthesis of these adsorbents (Yongjun Chen et al., 2007; Zarzycki J. et al., 1997).

"Sol-gel" technique comprises various steps as illustrated in Figure 1, starting with the preparation of a sol containing a precursor, followed by aging and deposition of the sol on a suitable support, then evaporation of the solvent and volatile compounds for gel formation and finally heat treatment for pyrolysis of remaining organics and densification of the film. 


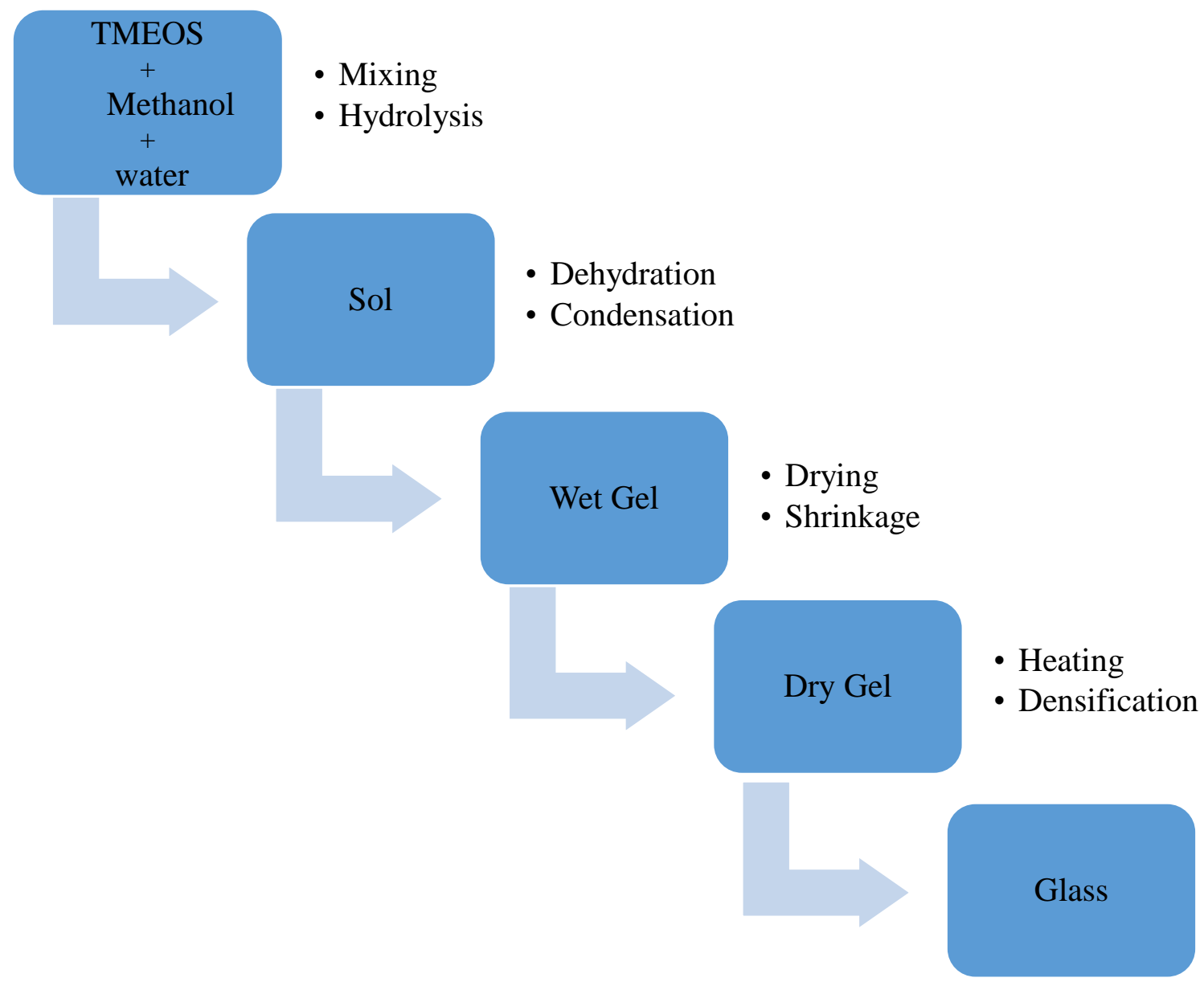

Figure 1 Steps for preparation of the sol-gel.

To form a gel, the alkoxide ( $\equiv \mathrm{Si}-\mathrm{OR}$ ) undergoes hydrolysis to form the silane ( $\equiv \mathrm{Si}-\mathrm{OH}$ ), which undergoes condensation to give siloxane ( $\equiv \mathrm{Si}-\mathrm{O}-\mathrm{Si} \equiv)$. Formation of sol-gel takes place via ageing and drying of sol-gel(Reeta $V$. et. al., 2008).

$$
\begin{aligned}
& \equiv \mathrm{Si}-\mathrm{OR}+\mathrm{H}_{2} \mathrm{O} \rightarrow \equiv \mathrm{Si}-\mathrm{OH}+\mathrm{ROH} \text { Hydrolysis } \\
& \left\{\begin{array}{l}
\equiv \mathrm{Si}-\mathrm{OH}+\equiv \mathrm{Si}-\mathrm{OR} \rightarrow \mathrm{Si}-\mathrm{O}-\mathrm{Si} \equiv+\mathrm{ROH} \\
\equiv \mathrm{Si}-\mathrm{OH}+\equiv \mathrm{Si}-\mathrm{OH} \rightarrow \equiv \mathrm{Si}-\mathrm{O}-\mathrm{Si} \equiv+\mathrm{H}_{2} \mathrm{O}
\end{array}\right.
\end{aligned}
$$

Hydrolysis and Condensation reactions involved in sol-gel formation

The gels form silicates since they are neither highly electropositive nor liable to nucleophilic reactions (Rios $\boldsymbol{P}$. F. et al., 2007).

"Sol-gel" can be prepared in numerous forms, including porous structures, thin fibers, dense powders and thin films (Gellermann $C$ et al., 1997). Sol-gel technologies have been successfully 
used to remove $\mathrm{CO}_{2}$ emissions from the atmosphere and there has been various attempts to synthesize new sol-gel products and processes that enhance the efficiency and rate for removal of $\mathrm{CO}_{2}$ emissions (Babak S. et al., 2014; Bhagat S. D. et al., 2008; Smith S. 2008). The sol-gel process has been widely used in preparing oxide-based films on a variety of substrates, such as the synthesis of hydrophobic silica nanoparticles(Smith S. et al., 2008; Rios P. F. et al., 2008; Hou H. et al., 2007; StöberW. et al., 1968) and surfaces(Nüchter M. et al., 2004; Rao K. J. et al., 1999; Ferreira M.B. et al., 2000). Monodispersed spherical silica nanoparticles were originally developed by Stöber(Mario A. et al., 2012), where aqueous alcoholic solutions of silicon alkoxide $\mathrm{Si}(\mathrm{OR})_{4}$ were used at high $\mathrm{pH}$ and different sized silica particles were prepared depending on the water and ammonia (catalyst) concentrations. TEOS, $\mathrm{Si}\left(\mathrm{OC}_{2} \mathrm{H}_{5}\right)_{4}$, was used as the precursor and its hydrolysis proceeded as follows:

$$
\mathrm{Si}(\mathrm{OR})_{4}+\mathrm{H}_{2} \mathrm{O} \rightarrow \mathrm{HO}-\mathrm{Si}(\mathrm{OR})_{3}+\mathrm{R}-\mathrm{OH}
$$

In some instances, hydrolysis may proceed to completion to silica depending on the amount of water and catalyst used according to the following equation:

$$
\mathrm{Si}(\mathrm{OR})_{4}+2 \mathrm{H}_{2} \mathrm{O} \rightarrow \mathrm{SiO}_{2}+4 \mathrm{R}-\mathrm{OH}
$$

Intermediate species including $\left[(\mathrm{OR})_{2}-\mathrm{Si}-(\mathrm{OH})_{2}\right]$ or $\left[(\mathrm{OR})_{3}-\mathrm{Si}-(\mathrm{OH})\right]$ may also be formed as products of partial hydrolysis reactions. Early intermediates are formed from two partially hydrolyzed monomers linked with a siloxane $[\mathrm{Si}-\mathrm{O}-\mathrm{Si}]$ bond.

$$
(\mathrm{OR})_{3}-\mathrm{Si}-\mathrm{OH}+\mathrm{HO}-\mathrm{Si}-(\mathrm{OR})_{3} \rightarrow\left[(\mathrm{OR})_{3} \mathrm{Si}-\mathrm{O}-\mathrm{Si}(\mathrm{OR})_{3}\right]+\mathrm{H}-\mathrm{O}-\mathrm{H}
$$

or

$$
(\mathrm{OR})_{3}-\mathrm{Si}-\mathrm{OR}+\mathrm{HO}-\mathrm{Si}-(\mathrm{OR})_{3} \rightarrow\left[(\mathrm{OR})_{3} \mathrm{Si}-\mathrm{O}-\mathrm{Si}(\mathrm{OR})_{3}\right]+\mathrm{R}-\mathrm{OH}
$$

As a result, polymerization occurs by the formation of a 1-, 2-, or 3-dimensional network of siloxane $[\mathrm{Si}-\mathrm{O}-\mathrm{Si}]$ bonds accompanied by the production of $\mathrm{H}-\mathrm{O}-\mathrm{H}$ and $\mathrm{R}-\mathrm{O}-\mathrm{H}$ species.

Recently, using microwaves as an energy source for chemical reactions and processes has been of great interest (Rao K. J. et al., 1999; Ferreira M. B. et al., 2000), since microwave-assisted synthesis offers faster, cleaner and more cost-effective synthesis routes than the conventional methods. Although the exact mechanism of interaction is not yet elucidated, the rapid heating achieved by microwaves could be owed to energy transfer occurring through resonance or relaxation. In microwave operation, heating is internally generated in the materials and consequently smaller thermal gradients are created which, in turn, potentially reduces cracking during the drying process (Mario $\boldsymbol{A}$. et al., 2012). In addition to the main advantage that microwave heating reduces time, it reduces energy consumption (Ahmed M. S. et al., 1998). 
The aim of the present work is to synthesize sol-gel glasses to be utilized for water treatment applications. Plain sol-gel glasses and others doped with neodymium, urea and thiourea will be prepared using convenient thermal heating followed by microwave irradiation. These formulations will be henceforth referred to as $\mathrm{P}, \mathrm{Nd}, \mathrm{U}$, and THU, respectively. The as-prepared sol-gel glasses will be tested for their adsorption capacity to remove Methylene Blue (MB) dye from aqueous solutions and their characteristic functional groups that might be responsible for adsorption will be determined by Fourier Transform Infrared Spectroscopy (FTIR). MB is an organic cationic water soluble dye that is used heavily in the textile industry and could also be found in industrial effluents (Bayoumi et al., 2018; Hameed B. H. et al., 2007; Santos A. et al., 2007).

\section{Materials and Methods}

\section{II.1 Materials}

Tetramethoxysilane (TMEOS),Fluka (98\%, MW 152.22, density 1.027), Neodymium Oxide $\left(\mathrm{Nd}_{2} \mathrm{O}_{3}\right)$, Sigma-Aldrich (99.99\%), Urea (Carbamide), Sigma-Aldrich (98\%, MW 60.06), Thiourea (Thiocarbamide), Sigma Aldrich (99\%, MW 76.12), and Methylene Blue, Sigma Aldrich (82\%, MW 319.85) were used.

\section{II.2 Characterization}

The as-prepared sol-gel glasses were characterized by Fourier Transform Infrared (FTIR)spectroscopy (Thermo Scientific, Nicolet 380), using 1-mm KBr pellets at a range of wave numbers of 500 to $4000 \mathrm{~cm}^{-1}$.

\section{II.3 Experimental}

\section{Preparation of Plain Sol-gel (P)}

Plain sol-gel glass has been prepared at $\mathrm{pH}$ 2.5, by mixing solutions of TMEOS, methanol, distilled water andconcentrated nitric acid with molar ratios 0.05: 0.35: 0.55: 0.039, respectively, followed by stirring the mixed solution for 30 minutes at room temperature, and then heated in an oven adjusted at $60^{\circ} \mathrm{C}$ for 7 days. Sample was then solidified and finally subjected to a microwave irradiation for 6 minutes (Olympic electric, model no. KOG-134K, Egypt, Power 20). Evaporation of the solvents led to shrinking and cracking of the plain sol-gel glass formed.

\section{Preparation of Sol-gel with Inorganic Dopant}

\section{With Metal Oxide $\left(\mathrm{Nd}_{2} \mathrm{O}_{3}\right)$ Dopant $(\mathrm{Nd})$}

Neodymium sol-gel glass has been prepared at $\mathrm{pH}$ 2.5, by mixing solutions of $\mathrm{Nd}_{2} \mathrm{O}_{3}, \mathrm{TMEOS}_{\text {, }}$ methanol, distilled water andconcentrated nitric acid with molar ratios0.027: 0.05: 0.35: 0.55: 0.039 , respectively, followed by stirring the mixed solution for 30 minutes at room 
temperature, and then heated in an oven adjusted at $60^{\circ} \mathrm{C}$ for 7 days. Sample was then solidified and finally subjected to a microwave irradiation for 6 minutes (Olympic electric, model no. KOG-134K, Egypt, Power 20). Evaporation of the solvents led to shrinking and cracking of the sol-gel glass formed.

\section{Preparation of Hybrid Sol-gel (with Organic Dopants)}

\section{Urea (Carbamide) (U) or Thiourea (Thiocarbamide) (THU)}

Hybrid sol-gel glasses were prepared in a manner similar to that of the inorganic doped glasses that is previously explained, but the organic dopant added is either urea or thiourea in an amount with molar ratio $0.039 \mathrm{~mol}$.

\section{Physical Properties of the Prepared Sol-gel Glasses}

The optical properties and particle sizes of the prepared sol-gel glasses have been measured, recorded and given in Table 1 . Clearly, THU has the smallest particle size range $(<250)$, while the size of the other three sol-gel glasses ranges from 250- 630 microns. Among the prepared solgel glasses, $\mathrm{Nd}$ exhibited the darkest color due to the presence of the transition element oxide $\left(\mathrm{Nd}_{2} \mathrm{O}_{3}\right)$. The results obtained are given in fig. 2 .

Table 1: Some of the physical characteristics of the as-prepared sol-gel glasses

\begin{tabular}{cccc}
\hline Sol gel glass & Transparency & Color & $\begin{array}{c}\text { Particle size } \\
\text { (microns) }\end{array}$ \\
\hline $\mathrm{P}$ & Transparent & Colorless & $500-630$ \\
$\mathrm{U}$ & Transparent & Light brown & $500-630$ \\
$\mathrm{THU}$ & Opaque & Pale yellow & $<250$ \\
$\mathrm{Nd}$ & Opaque & Purple & $250-500$ \\
\hline
\end{tabular}

\section{II.4 Sorption of Methylene Blue (MB)Using Prepared Sol-gel Glasses}

A mass of $0.01 \mathrm{~g}$ of each sol-gel glass prepared was added to $10 \mathrm{~mL}$ solutions of methylene blue (MB) with four different concentrations ranging from 2 to $12 \mathrm{mg} / \mathrm{L}$. Themixtures were then heated for 4 hourson a thermostatic shaking water bath (Shaking water bath (biobasebiodustry (Shandong) Co., Ltd, model SWB-C, China), adjusted at $27 \pm 1^{\circ} \mathrm{C}$, after which were centrifuged for 5 minutes at $300 \mathrm{rpm}$. The supernatants were collected and their absorbances were measured using UV-VIS spectroscopy (Cary 500 Scan, Varian). All measurements were performed in duplicates and the concentrations were obtained from absorbances using a calibration curve, 
while the amount of MB adsorbed at equilibrium $(q)$ was calculated using the following mass balance relation:

$$
q=\frac{\left(C_{0}-\mathrm{C}\right) V}{\mathrm{~m}}
$$

Where $C_{0}$ is the MB initial concentration, $V$ is the solution volume, and $m$ is the mass of the solgel adsorbent.

The removal efficiency could be calculated using the following equation:

$$
\% \text { Removal }=\frac{\left(C_{0}-\mathrm{C}\right)}{C_{0}} \times 100(6)
$$

The results obtained are given in Tables 2-5.

Table 2: Methylene blue and (P) (Thermal followed by MW)

\begin{tabular}{|c|c|c|c|c|}
\hline $\mathrm{C}_{0}$ & $\mathrm{~A}$ & $\mathrm{C}$ & \% removal & $\mathrm{q}, \mathrm{mg} / \mathrm{g}$ \\
\hline 12.5 & 1.696 & 9.28298 & 25.73618 & 6.43404 \\
\hline 6.25 & 0.354 & 1.9376 & 68.99836 & 8.62479 \\
\hline 3.125 & 0.338 & 1.85003 & 40.79912 & 2.54995 \\
\hline 1.575 & 0.1508 & 0.8254 & 47.59385 & 1.49921 \\
\hline
\end{tabular}

Table 3: Methylene blue and(U) (Thermal followed by MW)

\begin{tabular}{|r|c|c|c|c|}
\hline \multicolumn{1}{|c|}{$\mathrm{C}_{0}$} & $\mathrm{~A}$ & $\mathrm{C}$ & \% removal & $\mathrm{q}, \mathrm{mg} / \mathrm{g}$ \\
\hline 12.5 & 1.135 & 6.21237 & 50.301 & 12.5753 \\
\hline 6.25 & 1.122 & 6.14122 & 1.74056 & 0.21757 \\
\hline 3.125 & 0.4824 & 2.64039 & 15.5074 & 0.96921 \\
\hline 1.575 & 0.0484 & 0.26492 & 83.18 & 2.62017 \\
\hline
\end{tabular}


Table 4: Methylene blue andTHU (Thermal followed by MW)

\begin{tabular}{|c|c|c|c|c|}
\hline $\mathrm{C}_{0}$ & $\mathrm{~A}$ & $\mathrm{C}$ & \% removal & $\mathrm{q}, \mathrm{mg} / \mathrm{g}$ \\
\hline 12.5 & 1.628 & 8.91078 & 28.7137 & 7.17843 \\
\hline 6.25 & 1.1021 & 6.03229 & 3.48331 & 0.43541 \\
\hline 3.125 & 0.5561 & 3.04379 & 2.5988 & 0.16242 \\
\hline 1.575 & 0.1408 & 0.77066 & 51.0691 & 1.60868 \\
\hline
\end{tabular}

Table 5: Methylene blue and Nd (Thermal followed by MW)

\begin{tabular}{|c|c|c|c|l|}
\hline $\mathrm{C}_{0}$ & $\mathrm{~A}$ & $\mathrm{C}$ & \% removal & $\mathrm{q}, \mathrm{mg} / \mathrm{g}$ \\
\hline 12.5 & 1.6106 & 8.815544609 & 7.368910783 & 1.316480569 \\
\hline 6.25 & 0.849521 & 4.649813903 & 3.200372195 & 25.60297756 \\
\hline 3.125 & 0.295559 & 1.617728517 & 3.014542967 & 48.23268747 \\
\hline 1.575 & 0.167492 & 0.9167597154 & 1.316480569 & 41.79303394 \\
\hline
\end{tabular}

\section{Results and Discussion}

Sorption capacities of the different synthesized sol-gel glasses and their \% removal for 2 and 12 $\mathrm{mg} / \mathrm{L}$ of $\mathrm{MB}$ are shown in Figures3A and B, respectively. It can be observed that the highest sorption capacity and \% removal for the two employed MB concentrations were achieved by $\mathrm{U}$. For the highest concentration; $12 \mathrm{mg} / \mathrm{L}$ of $\mathrm{MB}$, U demonstrated a sorption capacity of $12.6 \mathrm{mg} / \mathrm{g}$ with a removal efficiency of $50.3 \%$. The corresponding values for the lowest concentration; $2 \mathrm{mg} / \mathrm{L}$ of $\mathrm{MB}$ were $2.6 \mathrm{mg} / \mathrm{g}$ and $83.2 \%$, respectively. Increase in removal efficiency with concentration was reported in previous literature (El-Sayed and El-Sayed, 2014). Furthermore, sorption capacity and removal efficiency achieved by $U$ were almost twice and 1.7 times those obtained by $\mathrm{P}$ at the higher and lower MB concentrations, respectively. This indicates that doping the plain sol-gel glass with urea enhanced its sorption characteristics probably due to the introduction of urea functional groups to the plain sol-gel. As for THU and Nd, they both showed comparable sorption capacities and removal efficiencies to that of $\mathrm{P}$ at the two employed $\mathrm{MB}$ concentrations; thus implying that neither doping with neodymium oxide $\left(\mathrm{Nd}_{2} \mathrm{O}_{3}\right)$ nor thiourea(THU) affected the sorption behavior of the sol-gel. Doping with neodymium oxide did not introduce any new functional groups to the sol-gel matrix and probably did not alter its pore structure in the manner that would affect its sorption capacity. Although thioureaintroduces new 
functional group to the sol-gel, yet it might have been used up in binding to the sol-gel matrix. In addition,thethiocarbonyl group of thioureacouldbe less reactive than the carbonyl group of ureatowards binding with MB, due to the electron deficiency of sulfur.<smiles>CN(C)c1ccc2nc3ccc(N(C)C)cc3[s+]c2c1</smiles>

Ionic Structure of Methylene Blue (Methylthioninium chloride)

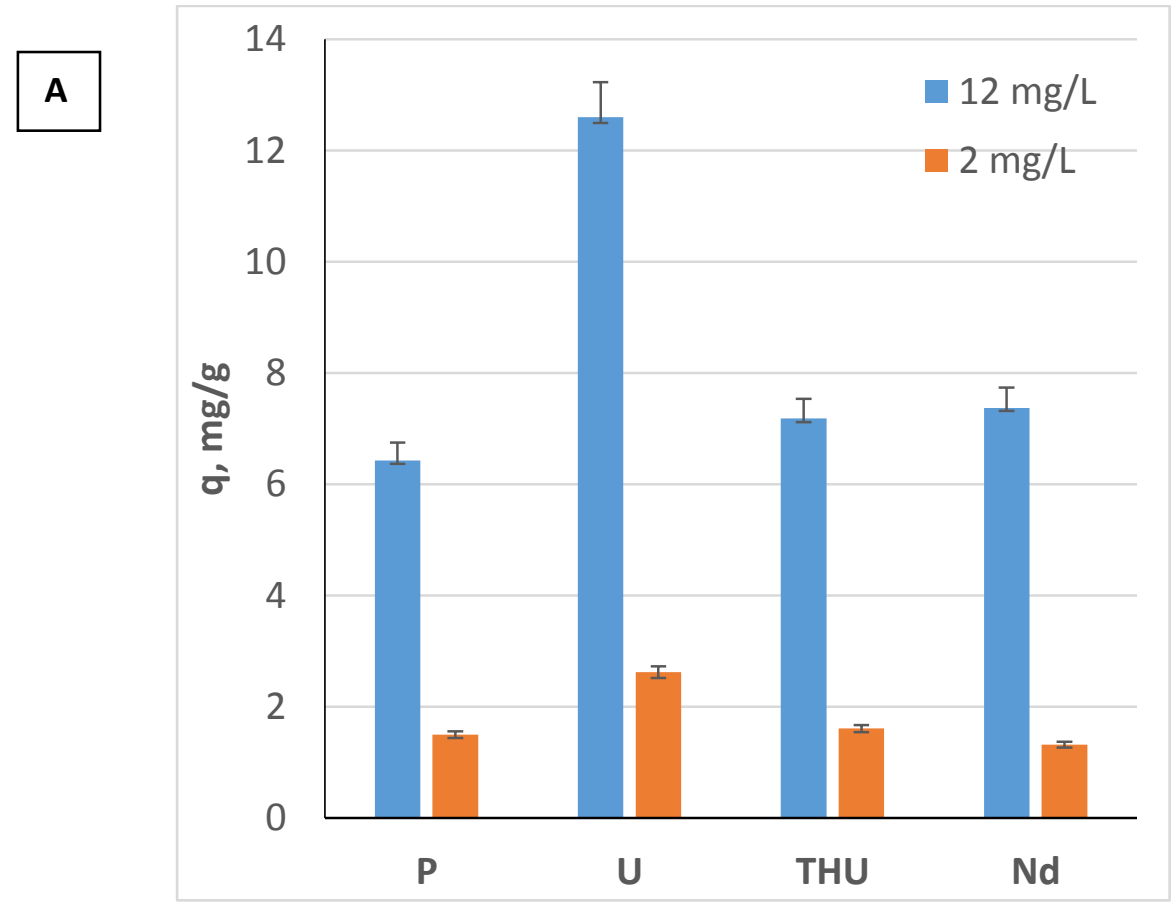




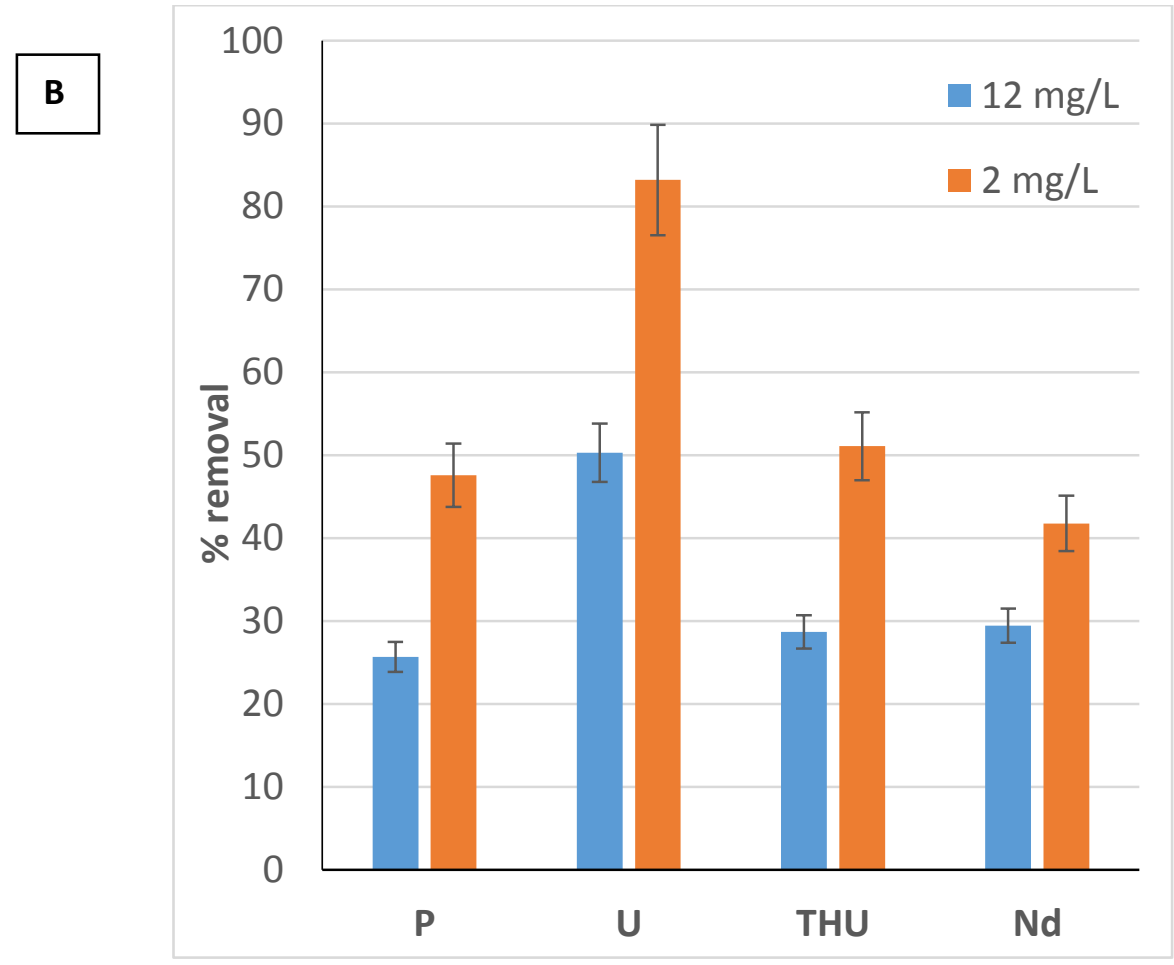

Figure 3 Sorption capacities (A) of different concentrations of the prepared sol gel glasses and their \%removal (B) for MB dye.

However, methylene blue (MB)is a well-known photosensitizer that tends to aggregate. Its aggregation negatively interferes with its singlet oxygen generation, thus MB aggregates tend to undergo electron transfer reactions, rather than energy transfer with oxygen.The high sorption efficiency of $U$ to MBcould be attributed to the fact that urea destabilizes MB aggregates mainly by causing a decrease in the enthalpic gain of dimerization. This finding was reported in previous literature where they computed the free energy for the dimer association process $(\Delta \mathrm{G}($ dimer $))$ in aqueous solution as well as its enthalpic component in aqueous and in aqueous/urea solutions by molecular dynamics simulations, and they foundthatMB monomers are more stable in urea solutions(Nuñez, SC et. al.,2015).

In addition, the interaction between $\mathrm{MB}$ and $\mathrm{U}$ could be due to an electrostatic attraction between the positively charged nitrogen or sulfur in $\mathrm{MB}$ and the lone pair of electrons on the carbonyl oxygen in urea, or alternatively via redox reaction between both of them. These properties are less pronounced in thiourea due to the acidity of electron deficient sulfur. The different forms of urea and thiourea are shown in Figure 4. 
<smiles>NC(N)=O</smiles>

Amine form
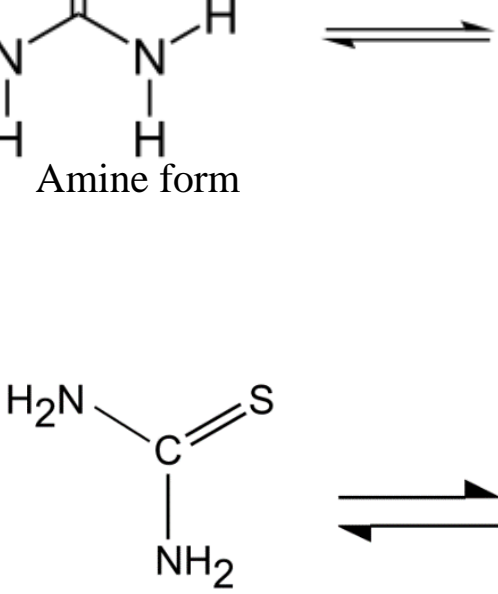

Thione form

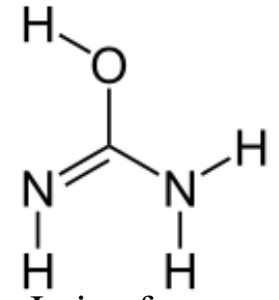

Imine form

Figure 4 Different forms of urea and thiourea

By inspecting the FTIR spectra of the synthesized sol-gel glasses (Figure 5), it can be inferred that $\mathrm{P}$ and $\mathrm{Nd}$ (Figures5 A and 5D) prior to adsorption exhibit a broad peak at about 3430-3470 $\mathrm{cm}^{-1}$ pertaining to the $\mathrm{OH}$ stretching vibration, while after adsorption this peak is slightly shifted. In addition, Nd shows a peak for the stretching vibration of Si-OH at about $942 \mathrm{~cm}^{-1}$ before adsorption which disappears after adsorption, while $\mathrm{P}$ exhibits a peak at $959 \mathrm{~cm}^{-1}$ which shifts to $972 \mathrm{~cm}^{-1}$ after adsorption. $\mathrm{P}$ also shows two peaks at 1650 and $1383 \mathrm{~cm}^{-1}$ which could be attributed to the stretching vibration of the $\mathrm{C}=\mathrm{O}$ group and the bending vibration of the $\mathrm{CH}_{3}$ group, respectively and these peaks remain unchanged after adsorption. The corresponding peaks for $\mathrm{Nd}$ appear at 1666 and $1342 \mathrm{~cm}^{-1}$ and these are shifted after adsorption. For both $\mathrm{P}$ and $\mathrm{Nd}$, the peaks appearing before adsorption at about $1087 \mathrm{~cm}^{-1}$ remain unchanged after adsorption and these could be ascribed to the asymmetric vibration of Si-O-Si.

For U and THU (Figures5B and 5C), the peak shown before adsorption at about 3415-3425 $\mathrm{cm}^{-1}$ could be ascribed to the NH stretching vibration while the peak at about $3100 \mathrm{~cm}^{-1}$ could be attributed to the $\mathrm{CH}$ stretching vibration, and these peaks merge into one broad peak after adsorption. Furthermore, the $\mathrm{CH}_{3}$ bending vibration peak appearing for $\mathrm{U}$ and THU before adsorption at $1384 \mathrm{~cm}^{-1}$ is not altered after adsorption, whereas the carbonyl peaks appearing at about $1650-1669 \mathrm{~cm}^{-1}$ prior to adsorption are slightly shifted after adsorption which confirms the interaction referred to earlier between the carbonyl group and MB. Moreover, the Si-O-Si peaks appearing for both $\mathrm{U}$ and THU at $1080 \mathrm{~cm}^{-1}$ before adsorption are slightly shifted after adsorption. 

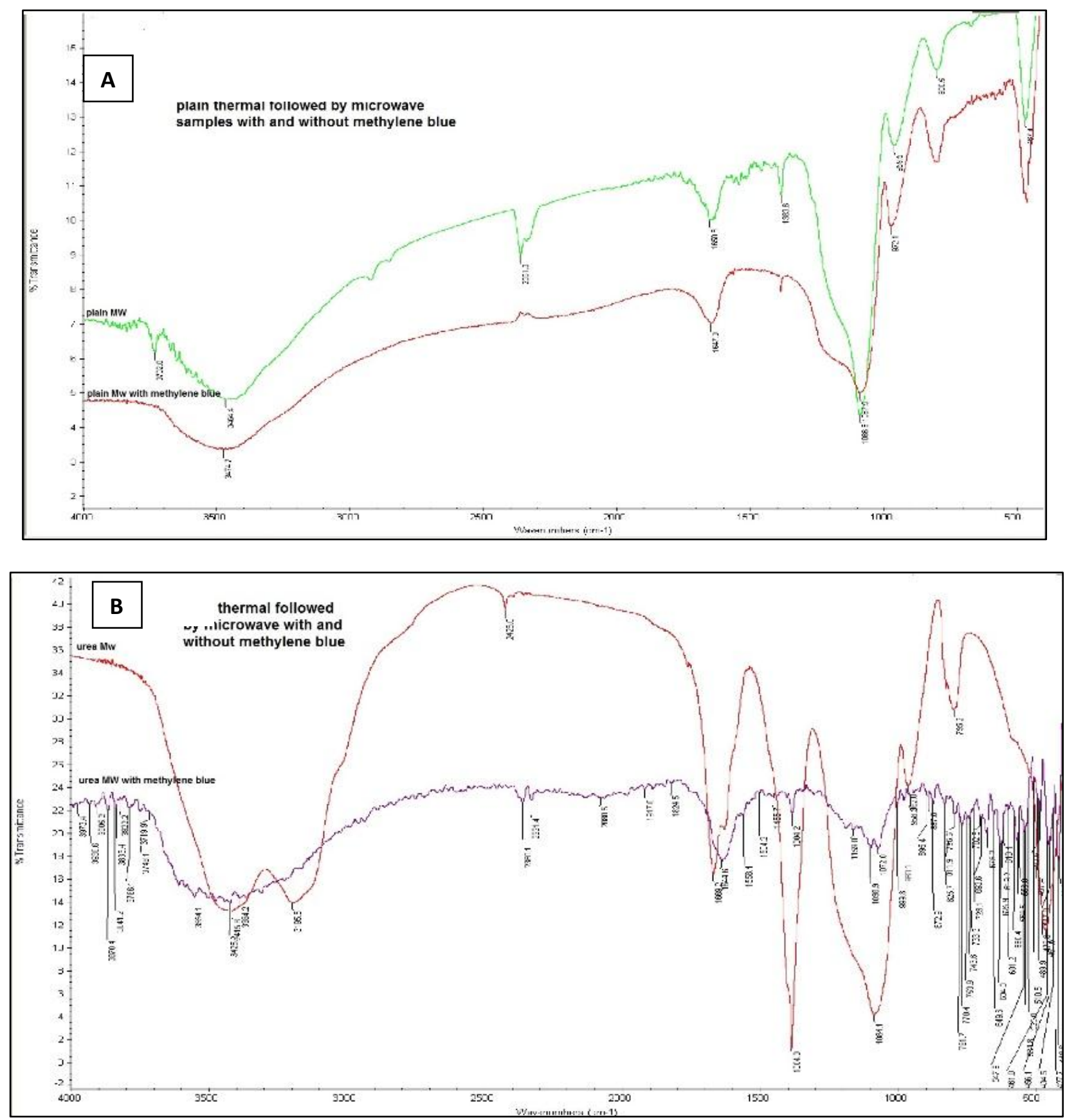
J. Sci. Res. Sci., Vol.(35), 2018
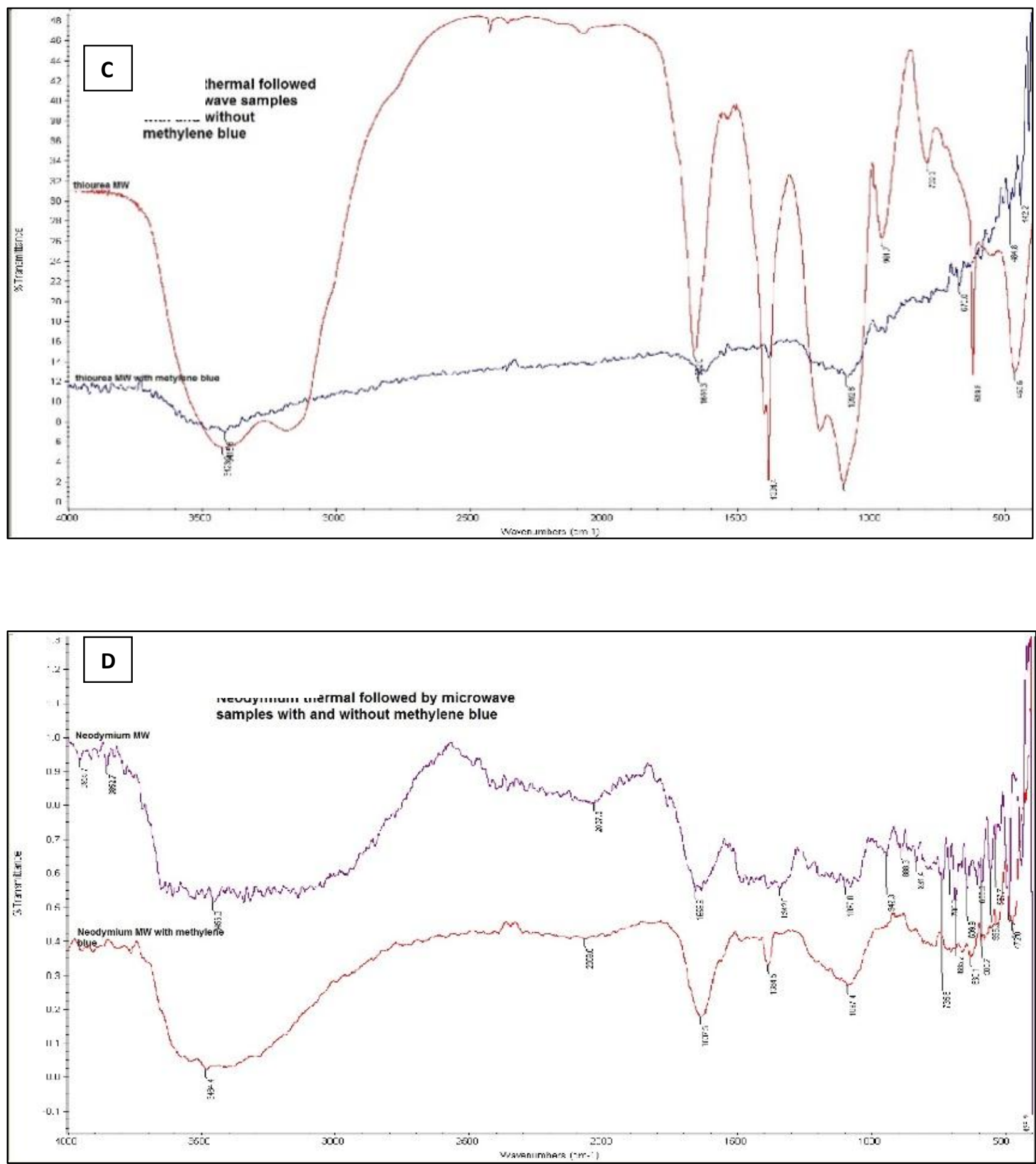

Figure 5 FTIR spectra of the prepared sol-gel glasses $(\mathrm{P}(\mathrm{A}), \mathrm{U}(\mathrm{B}), \mathrm{THU}(\mathrm{C})$ and $\mathrm{Nd}(\mathrm{D}))$, before and after adsorption. 


\section{Conclusion}

Different doped and undoped sol-gel glasses were prepared by thermal followed by microwave treatment. The urea-doped glasses showed the highest sorption capacity and \% removal for MB from aqueous solutions probably due to interaction between the nitrogen or sulfur groups on MB and the carbonyl carbon on urea. This interaction was confirmed by FTIR analysis.

\section{Acknowledgements}

Thanks are due to the chemistry Department, Faculty of Women for Arts, Science and Education, Ain Shams University and American University in Cairo for providing all facilities to accomplish this work.

\section{References}

Ahmed M. S., Attia Y. A. Multi-metal oxide aerogel for capture of pollution gases from air. App Thermal Eng. (1998) 18,787-797.

BabakSamiey, Chil-Hung Cheng, and Jiangning Wu, Materials(2014) 7, 673-726.

Bayoumi, O., Haithem K., El-Sayed, M.M.H., Conventional versus ultrasonic biosorption of methylene blue onto fava bean peels, proceedings of the 13th Conference on Sustainable Development of Energy, Water and Environmental System (SDEWES), Palermo, Italy, 2018.

Bhagat S. D, Kim Y-H, Suh K-H, Ahn Y-S, Yeo J-G, Han J. H. Microporous Mater (2008) 112, 504.

Ferreira, M. P., Uso da RadiaçãoElectromagnética (Microondas,Ultravioleta $e$ Raios Gama)e do Campo MagnéticonoProcessamentoSol-gel da Sílica, Universidade Federal de MinasGerais,(2000) 177. (Ph.D Thesis).

Gellermann C., Storch W., Wolter H. J. Sol-Gel Sci Technol (1997) 8,173.

Hameed, B. H., and M. I. El-Khaiary, "Sorption Kinetics and Isotherm Studies of a Cationic Dye Using Agricultural Waste: Broad Bean Peel, Journal of Hazardous Materials (2008) 3, 154.

Hou H., Chen Y., J. Sol-Gel Sci Technol (2007) 43, 53.

Mario Aparicio, Andrei J. Lisa C. K., Morales-Flórez V., Esquivias L. and A. Santos, Sol-Gel Materials for Carbon Mineral Sequestration (2012) 177.

Nu“chter M., Ondruschka B., Bonrath W., Gum A., Green Chem. (2004) 6,128. 
Nuñez SC1, Yoshimura TM1, Ribeiro MS1, Junqueira HC2, Maciel C3, Coutinho-Neto MD3, Baptista MS, Urea enhances the photodynamic efficiency of methylene blue, J PhotochemPhotobiol B. (2015) Sep;150:31-7.

Rao K. J., Vaidhyanathan B., Ganguli M., RamakrishanP, A, Chem Mater (1999) 11, 882.

Reeta V., Sami A., Mika J., Mika K., Titania and Living Organisms (2008), pp. 253-269

Rios PF, Dodiuk H, Kenig S, McCarthy S, Dotan A PolymAdvTechnol (2008) 19, 1684.

Santos A, Toledo-Fernández J. A, Mendoza-Serna R, Gago-Duport L, De la Rosa-Fox N., Piñero $\mathrm{M}$, Esquivias L. Chemically active silica-wollastonite composites for $\mathrm{CO}_{2}$ fixation by carbonation reactions. Ind. Chem Eng. (2007) 46, 103-107.

Smith S., Shajesh P., Mukundan P., Warrier K., J Sol-Gel Sci. Technol (2008) 48, 356.

Stöber W., Fink A, Bohn E., J. Colloid Interface Sci. (1968) 26, 62.

Yongjun Chen, D. D. Dionysiou, Sol-Gel Synthesis of Nanostructured $\mathrm{TiO}_{2}$ Films For Water Purification, Proceedings of the NATO Advanced Research Workshop on Sol- Gel Methods for Materials Processing, Focusing on Materials for Pollution Control, Water Purification, and Soil Remediation, Kyiv, Ukraine (2007) 25-27 October, p. 67.

Zarzycki J., J. Sol-Gel Sci. Technol (1997) 8, 17. 


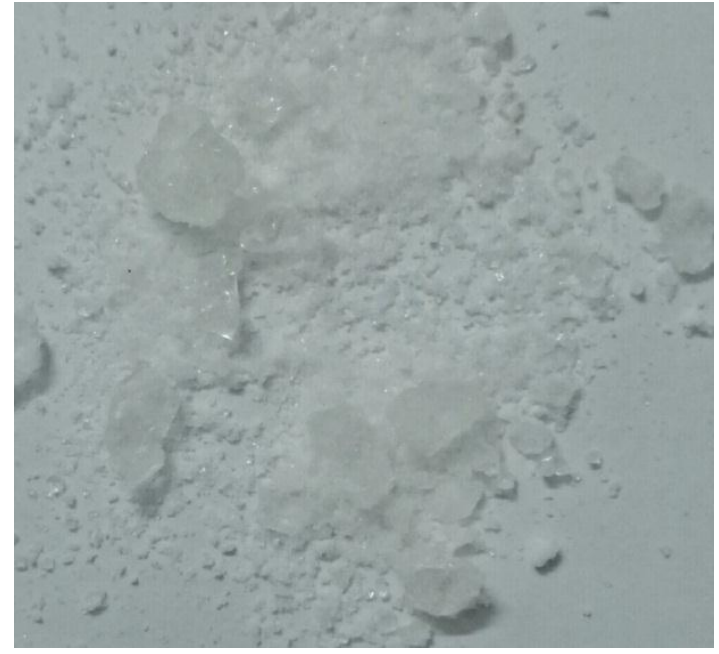

Plain sample thermal followed by microwave

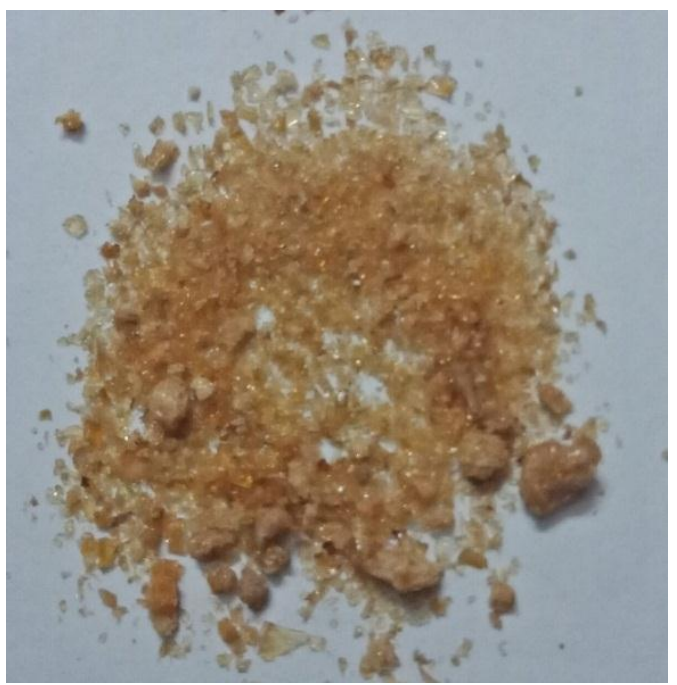

Urea doped thermal followed by microwave

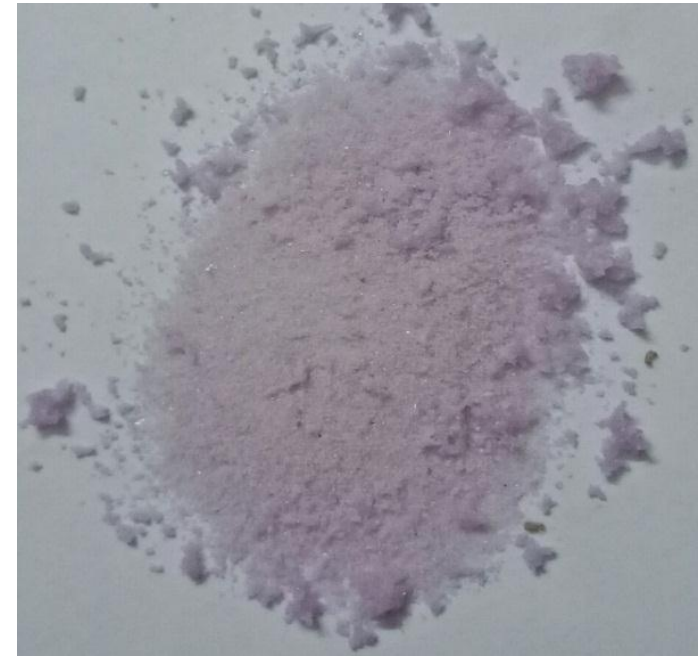

Neodymium oxide doped thermal followed by microwave

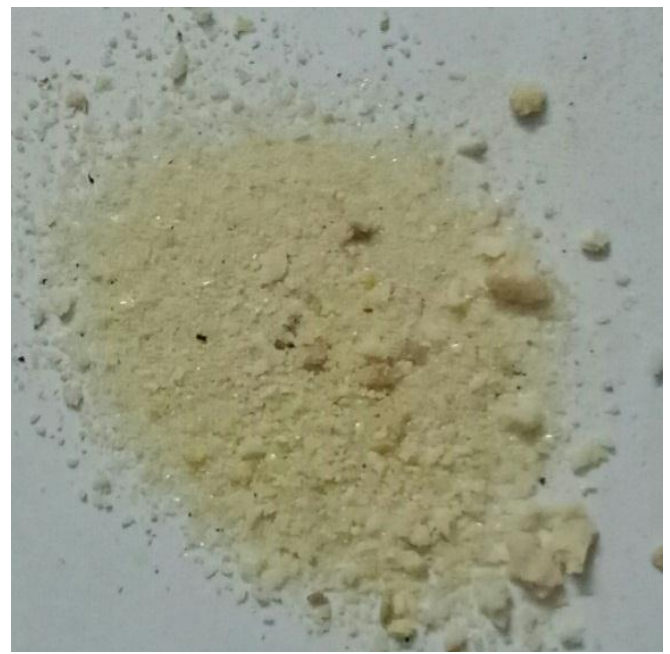

Thiorea doped thermal followed by microwave

Figure 2. Sol-gel Glasses Synthesized Using Convenient Thermal Heating Followed by Microwave Irradiation 


\section{الملخص باللغة العربية}

تم تحضير الصول - جيل الزجاجي من المركبات العضوية وغير العضوية وتم قياس خو اصهما الفيزيائية و الكيميائية للمقارنة بينها، كما تم در اسة مقارنة نشاطهم نحو إز الة مركب الميثيلين بلو الملوث للمياه و الناتج من صناعة النسيج. تم استخدام تتر اميثوكسي سيلان (TMOS)كدليل وبإضافة النيودينيوم، او اليوريا (الكاربامبد)، أو الثيويوريا (الثيوكاربامبد). تم أيضا المقارنة بين الصول جيل الزجاجي الذي تم تحضيره من خلال التسخين الحراري المعتاد وبين الذي تم تحضيره بالتسخين الحراري المعتاد ثم تعريضه لأشعة الميكروويف.وقد أطلق علي هذه المركبات فيما بعد THU,U,Nd, P علي التوالي. تم اختبار كفاءة ادمصاص الصول - جيل الزجاجي الذي تم تحضير هم نحو إزالة صبغة الميثيلين بلو من المحاليل المائية باستخدام قياسات الأشعة فوق البنفسجية للمحاليل، وتبين أن نشاط هذه المركبات نحو مقدرة ادمصاص صبغة الميثيلين الأزرق (Methylene Blue; MB) الملوثنةللماءوالناتجة من صناعة صباغة النسيج،يقع في الترتيب التالي: ,U> THU >Nd >>>> أي أن اليوريا تتميز بقوة ادمصاص لتنقية المياه من ملوثات الصناعة تفوق المركبات الأخري. أما عن حجم جزيئات الصول- جيل الزجاجي فكان أصغر هم حجما هو المتكون من الثيويوريا THUحيث تبين أنه أقل من • ب ب بينما كان حجم الثلاث مركبات الأخري يتراوح ما

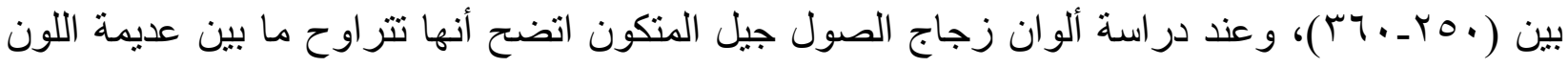

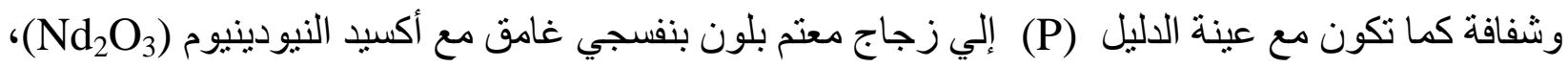
وهو عنصر انتقالي، زجاج الصول - جيل المتكون منه أغمق لونا فيهم (اللون البنفسي الغامق)، وتتراوح ألوان الزجاج صول - جيل التي تم تحضيرها بين عديمة اللون وشفافة (P)(إلي البنفجي الغامق (Nd) وخو اصها الضوئية من شفافة إلي معتمة. أما اليوريا (U) فقد أكسبته اللون البرتقالي والثيويوريا اللون الأصفر الليموني (THU) . وبدراسة تأثثر إثعاع الميكروويف علي العينات المحضرة من التسخين الحراري المعتاد فقد أدت إلي زيادة تصدع الصول - جيل الزجاجي المتكون بالإضافة إلي قتامة في لونه ويتضح ذللك مع اليوريا (U)حيث تحول اللون إلي البرتقالي الذي يميل إلي البني. تم التعرف علي المجموعات الفعالة في زجاج الصول - جيل الذي تم تحضيره و المسئولة عن ادمصاص صبغة)(MB)لتقية الماء الملوث

بها، من خلال القياسات الطيفية للأشعة تحت الحمر اء (FTIR) 